\title{
Stock assessment of the peacock bass Cichla temensis (Humboldt, 1821), an important fishing resource from the middle Negro river, Amazonas, Brazil
}

\author{
C. P. Campos C (D) M. F. Catarino $^{a}$ (D) and C. E. C. Freitas ${ }^{a}$ \\ ${ }^{a}$ Departamento de Ciências Pesqueiras, Universidade Federal do Amazonas - UFAM, Av. Gen. Rodrigo Otávio, 3000 , \\ Coroado, CEP 69077-000, Manaus, AM, Brasil \\ *e-mail:krolpc@gmail.com
}

Received: June 11, 2018 - Accepted: May 13, 2019 - Distributed: August 31, 2020

(With 2 Figures)

\begin{abstract}
Peacock bass Cichla temensis is an important species at the Amazon basin, since commercial, subsistence and recreational fisheries simultaneously exploit it. Cichla temensis is the preferred species by recreational fishers and it has been strongly exploited, mainly at the Negro river, the second largest tributary of the Amazon River. It was used data from experimental fisheries, collected at the middle stretch of Negro river, which were coupled with previously published data on its population dynamics, to run a yield per recruit model and build scenarios of sustainable fisheries. The results showed that the age of the first catch is a key variable to successful management of the peacock bass stocks at this region.
\end{abstract}

Keywords: stock assessment, simulation model, population dynamics, Amazon basin.

\section{Avaliação de estoque do tucunaré Cichla temensis, um importante recurso pesqueiro do médio rio Negro, Amazonas, Brasil}

\section{Resumo}

O tucunaré Cichla temensis é uma importante espécie de peixe da bacia Amazônica, uma vez que esta espécie é simultaneamente explotada pela pesca comercial e de subsistência. Além disso, é preferida pelos pescadores esportivos que atuam na região do rio Negro, o segundo maior afluente do rio Amazonas. Foram usados dados de pescarias experimentais, coletados no trecho médio do rio Negro. Estes dados foram vinculados a outros dados, previamente publicados, sobre sua dinâmica populacional, para executar um modelo de rendimento por recruta e, dessa forma, construir cenários para pesca sustentável dessa espécie. Os resultados mostraram que a idade da primeira captura é uma variável chave para gerenciar, com sucesso, os estoques de tucunarés nesta região.

Palavras-chave: avaliação de estoque, simulação de modelo, dinâmica populacional, bacia Amazônica.

\section{Introduction}

The Amazon basin hosts at least four types of fisheries: subsistence, artisanal small-scale, industrialized small-scale and recreational, which could be discriminated by noticeable characteristics, such as target species, type of vessels, type of fishers and fishing gears (Freitas and Rivas, 2006; Ruffino, 2014). Some species are simultaneously exploited by more than one fishery and the effect of the added fishing effort is difficult to address. Besides, the fishing intensities are broadly variable by species, populations, seasonality aquatic environmental and areas of the basin, but some stocks already exhibit over-fishing status (Isaac and Ruffino, 1996; Sant'Anna et al., 2014; Campos et al., 2015b).

The Cichla species are large piscivorous, can reach around $11 \mathrm{~kg}$ and more than $80 \mathrm{~cm}$ length (Jepsen et al., 1997; Campos et al., 2015a). They are broadly distributed over the basin, with several species inhabiting black waters of Orinoco and Negro river basins (Kullander and Ferreira, 2006), where they are exploited for feeding and recreational proposals (Jepsen et al., 1999; Barthem and Goulding, 2007; Inomata and Freitas, 2015). At the Negro river basin, Cichla temensis is the most attractive species for anglers, due its aggressive behavior and large body size (Holley et al., 2008). Several studies were developed on this species, describing its geographic distribution and resource use (Jepsen et al., 1997; Winemiller et al., 1997), color patterns and hybridism occurrence (Andrade et al., 2001; Brinn et al., 2004; Reiss et al., 2012), feeding behavior (Rabelo and Araújo-Lima, 2002), reproduction (Montaña et al., 2007) and populational genetics (Willis et al., 2015). Also growth studies were done for populations of 
the Orinoco River basin (Jepsen et al., 1997, 1999), and Negro river basin (Holley et al., 2008; Campos et al., 2015a) and a stock assessment was developed to Cichla monoculus (Agassiz, 1831) caught at the Lago Grande, a huge floodplain lake located at the left bank of the Solimões River, near to Manaus (Campos and Freitas, 2014). However, at this moment, there are no assessment studies to the stocks of $C$. temensis living at Negro river, where different fisheries have been acting on it.

Due the absence of fishing data to develop traditional stock assessment procedures, this manuscript taken data from experimental fisheries that generates growth parameters (Campos et al., 2015a) to estimate mortality parameters and simulate scenarios of sustainable fishing with different values of age at the first catch and fishing mortality. The simulation was based on a yield per recruit model and afterward some potential management strategies were discussed aiming to contribute for the sustainability of this important fishing resource.

\section{Material and Methods}

This study was conducted in the middle Negro river region (W $062^{\circ} \mathrm{C} 56$ ' 56.1" $\mathrm{S} 00^{\circ} 58^{\prime} 00.5^{\prime}$ "), in the proximities of Barcelos municipality in the state of Amazonas, Brazil (Figure 1). This is a typical blackwater river owing to the dark color of the water, resembling black tea and its middle stretch is characterized by the Mariuá Archipelago (Latrubesse and Franzinelli, 2005).

Samples of Cichla temensis were obtained between October 2011 and September 2012, on a monthly basis.
Samplings were experimental fisheries performed twice a day, from $6 \mathrm{~h} 00$ to $12 \mathrm{~h} 00$ and from $14 \mathrm{~h} 00$ to $18 \mathrm{~h} 00$, in the main channel of the river, the adjacent lakes as well as in the canals of the Mariuá archipelago. Fish were kept in coolers with ice and transported to Manaus for the retrieval of biological data: standard length $(\mathrm{cm})$ and total weight $(\mathrm{g})$. Although experimental fisheries, these were developed with the same fishing gear and strategies developed by anglers and was supposed that it could obtain truly the parameters of the exploited population.

Campos et al. (2015a) estimated the following growth parameters of von Bertalanffy equation and using the same dataset: asymptotic length $\left(L_{\infty}=68.05 \mathrm{~cm}\right)$, growth coefficient $\left(k=0.20 \cdot\right.$ year $\left.^{-1}\right)$ and longevity $\left(A_{0.95}=14.0\right.$ years $)$. The parameter $t_{0}$ was considered zero because the initial size of the individual is negligible and because this parameter has no biological relevance.

The ages of recruitment ( $T r$ ) [Equation 1] and first catch (Tc) [Equation 2] were estimated using an adaptation of the von Bertalanffy growth equation (King, 1995; Sparre and Venema, 1997), as follows:

$$
\begin{aligned}
& \operatorname{Tr}=t_{0}-\left(\frac{1}{k}\right) \cdot L n \cdot\left[1-\frac{L t}{L \infty}\right] \\
& T c=t_{0}-\left(\frac{1}{k}\right) \cdot L n \cdot\left[1-\frac{L t}{L \infty}\right]
\end{aligned}
$$

The length of the first catch and mean length of recruitment were estimated assuming that: $L c=L r=$ the smallest length class fully in the sampling (King, 1995; Sparre and Venema, 1997).

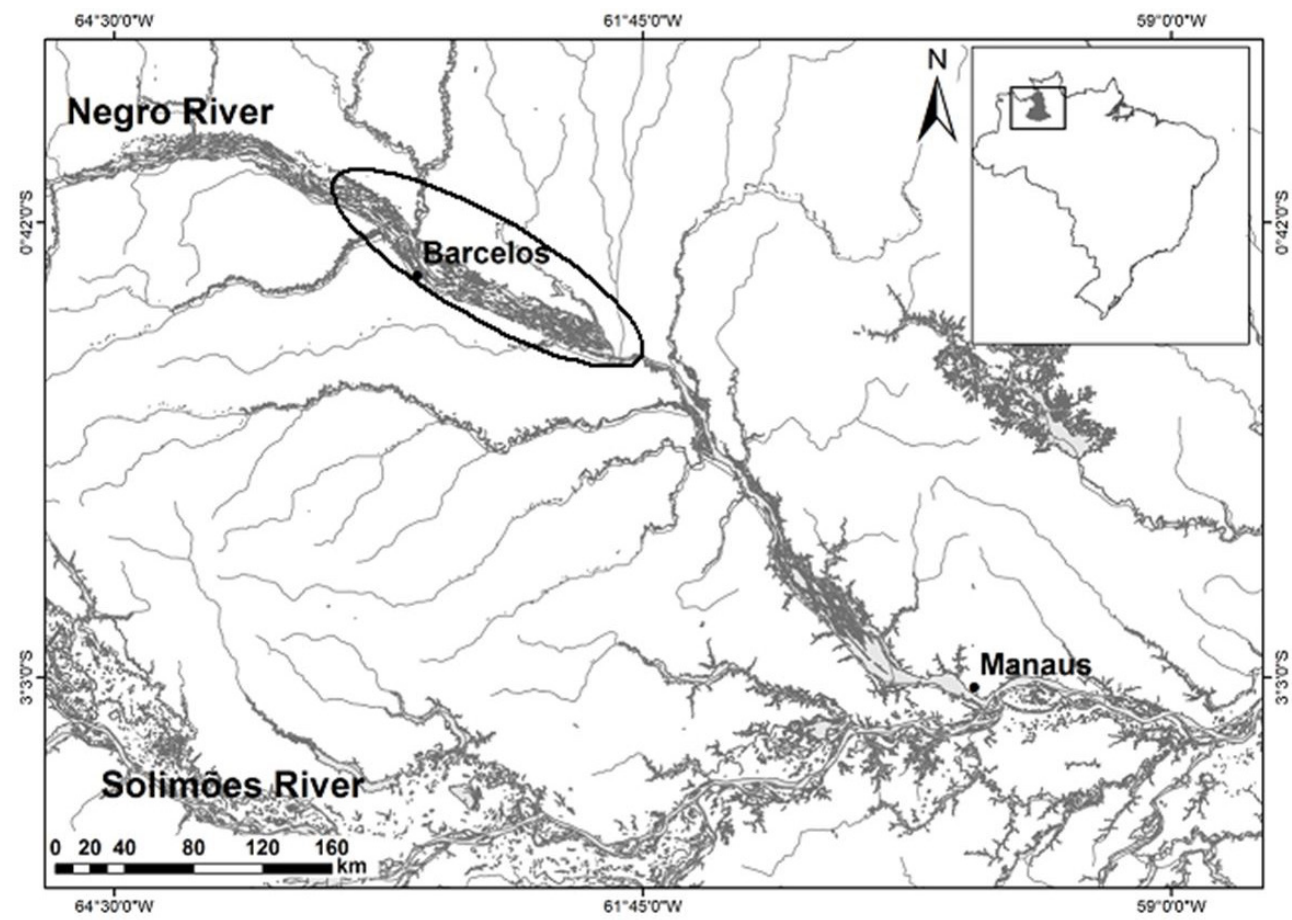

Figure 1. Middle Negro river, Amazonas, Brazil, showing the cities of Manaus and Barcelos. 
The parameters $a$ and $b$ of the weight and length relationship, as defined by the Equation:

$W=a \cdot L^{b}$

where $\mathrm{W}$ is the total weight and $\mathrm{L}$ is the standard length, were estimated employing a non-linear model using the Levenberg-Marquardt procedure. The obtained equation was employed to obtain an estimate of Maximum Theoretical Weight $\left(W_{\infty}\right)$

The natural mortality $(M)$ was estimated by Equation 4 (Pauly, 1980), which estimates the natural mortality using an empiric equation that establishes a relationship between the natural mortality, growth parameters, and the temperature at the water surface.

$\log M=-0.0066-0.279 \cdot \log L \infty+0.6543 \cdot \log k+0.4634 \cdot \log T$

where $L \infty$ and $k=$ the parameters of the von Bertalanffy growth equation and $T=$ the mean annual temperature at the water surface.

The total mortality $(Z)$ was estimated by the linearized catch curve (King, 1995), assuming that the stock density decreases by a rate proportional to the abundance of each age class. The age $(t)$ was estimated using the Equation 5:

$t=\frac{-L n \cdot\left(1-\left(\frac{L t}{L \infty}\right)\right.}{k}$

where $L n=$ natural logarithm; $L t=$ length at age $t$; $L \infty=$ asymptotic length. We assumed that $Z$ is the slope of the regression between the log-transformed values of density and age. After that, fishing mortality $(F)$ was estimated using the Equation 6:

$F=Z-M$

Scenarios of yield per recruit for different combinations of fishing mortality $(F)$ and age of the first catch $(\mathrm{Tc})$ were done using the Beverton and Holt model, as described by Sparre and Venema (1997) according to the Equation 7:

$Y / R=F \cdot \exp ^{[-M \cdot(T c-T r)]} \cdot W \infty$.

$\left[\left(\frac{1}{Z}\right)-\left(\frac{3 S}{Z+K}\right)+\left(\frac{3 S^{2}}{Z+2 K}\right)-\left(\frac{3 S^{3}}{Z+3 K}\right)\right]$

where $\mathrm{Y} / \mathrm{R}=$ the yield per recruit $\left(\mathrm{g} \cdot\right.$ recruit $\left.^{-1}\right) ; F=$ the fishing mortality; $M=$ the natural mortality; $T r=$ the age of recruitment; $T c=$ the age of the first catch; $W_{\infty}=$ the maximum theoretical weight; $Z=$ the total mortality; $S=\exp ^{\left[-k \cdot\left(T c-t_{0}\right)\right]} ; k=$ the intrinsic rate of growth and $t_{0}=$ the parameter of the von Bertalanffy equation.

\section{Results}

A total of 250 Cichla temensis specimens were collected. Standard length varied between 21.5 and $53.5 \mathrm{~cm}$ (mean $33.30 \pm 5.34 \mathrm{~cm}$ ). The natural mortality was calculated as $0.49 \cdot$ year $^{-1}$ and the total mortality $(Z)$ as $1.24 \cdot$ year $^{-1}$. As consequence, the fishing mortality was equal to $0.75 \cdot$ year $^{-1}$ (Table 1 ). The age of recruitment and the age of the first catch were assumed equal to 1.88 years, since the fish of this species became vulnerable for fishing at the same age they began to live at the adult stock.

The mean length of captured fish was $33.0 \mathrm{~cm}$, which correspond to an age of 3 years. The length of the first catch $(L c)$, which is the lower length fully represented at the catch was assumed as $21.5 \mathrm{~cm}$, based on fishing reports. Approximately 5\% of the collected fish showed length smaller than $25 \mathrm{~cm}$ (minimum fish size of fishing defined by Brazilian law).

\section{Discussion}

The results showed that age of the first catch is a key variable for a successful management of Cichla temensis exploited by commercial, subsistence and recreational fisheries at the middle Negro river. Nowadays, the Brazilian Agency responsible by the fishing management establishes the minimum size to fish peacock bass, main commercial Cichla species, as $25 \mathrm{~cm}$ (Dias-Neto and Dias, 2015). However, as an evidence of the law inconsistency, the size of first sexual maturation $\left(L_{50}\right)$ for $C$. temensis population of the middle Negro river was estimated in $31.1 \mathrm{~cm}$, correspond to an age around 3 years old (Campos et al., 2015a). Actually, if the catches are based on individuals below $25 \mathrm{~cm}$ they are exploring fishes younger than 2.26 years old (Table 2 ).

The peacock bass Cichla temensis is a large equilibrium species, in the sense of Winemiller and Rose (1992), with moderate to long generation time, low reproductive effort, large body size, low batch fecundity, high investment per offspring and, in general, no migratory behavior. By this way, its yield per recruit should be highest exploring individuals

Table 1. Population parameters of Cichla temensis caught at in the region of the middle Negro river (Amazonas, Brazil) between 2011 and 2012 .

\begin{tabular}{lc}
\hline \multicolumn{1}{c}{ Estimated population parameters } & $\mathbf{2 0 1 1 / 2 0 1 2}$ \\
\hline Total mortality $(Z)\left(\right.$ year $\left.^{-1}\right)$ & 1.24 \\
Natural mortality $(M)\left(\right.$ year $\left.^{-1}\right)$ & 0.49 \\
Fishing mortality $(F)\left(\right.$ year $\left.^{-1}\right)$ & 0.74 \\
Maximum theoretical weight $\left(W_{\infty}\right)(\mathrm{g})$ & $5,037.63$ \\
Age of recruitment $(T r)$ (year) & 1.88 \\
Age at first capture $(T c)($ year $)$ & 1.88 \\
Length at first capture $(L c)(\mathrm{cm})$ & 21.5 \\
\hline
\end{tabular}

Table 2. Criteria employed to associate length intervals (L.I.) to age intervals (A.I.) of the Cichla temensis caught at the middle Negro river (Amazonas, Brazil), from 2011 to 2012.

\begin{tabular}{lcc}
\hline \multicolumn{1}{c}{ Criteria } & L.I. (cm) & A.I. (years) \\
\hline $1-$ Length $<L_{\text {law }}{ }^{*}$ & $21.5-24.9$ & $1.88-2.26$ \\
$2-L_{\text {law }}<$ Length $<L_{50} * *$ & $25.0-30.9$ & $2.27-3.00$ \\
$3-$ Length $\geq L_{50}$ & $31.0-53.5$ & $3.01-7.64$ \\
\hline
\end{tabular}

*Minimum fish size of fishing of Cichla spp. defined by Brazilian law. **Length at sexual maturity of Cichla temensis. 


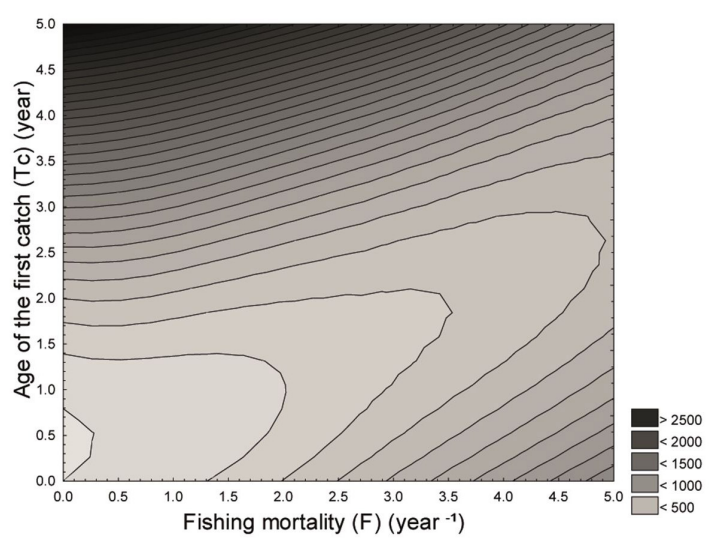

Figure 2. Simulation the yield per recruit of Cichla temensis for different combinations of age at first capture $(T c)$ and fishing mortality $(F)$. Each isoline represents a constant yield per recruit.

older than 3 years old, which is correspondent to a length above $31 \mathrm{~cm}$ that is its size of first sexual maturation (Figure 2; Table 2). It is noticeable that exploiting a fishing based on an age of the first catch below 2 will not obtain yields per recruit above $0.50 \mathrm{~g} \cdot \mathrm{g}^{-1}$ independent of the fishing mortality coefficient (Figure 2).

The yield per recruit model is an efficient approach for fish stock assessment, consisting in an important tool to the management of fisheries (Sparre and Venema, 1997). Nevertheless, its efficacy has been criticized because recruitment and natural mortality are assumed as constant. Another constraints could arise in multispecies fisheries, as happens at the Amazon basin, since this model do not include the complex interactions among species (Pauly, 1980). Moreover, the model establishes reference points for management purposes, but none hypothesis tests are performed during the stock assessment process.

In general, the fishing effort $(f)$ and the age of the first catch $(T c)$ are the viable goals for fishing management (Sparre and Venema, 1997). However, the fishing effort is a very difficult task in small-scale fisheries as performed in the Amazon basin (Bayley and Petrere, 1989; Batista and Petrere Junior, 2007; Batista et al., 2012). As the age of thąe first catch $(T c)$ is directly associated with the size of the first catch $(L c)$, other studies already proposed a fishing management based on it as an option for small-scale fisheries developed on the stocks of Cichla monoculus (Campos and Freitas, 2014), Prochilodus nigricans (Spix et Agassiz, 1829) (Catarino et al., 2014) and Colossoma macropomum (Cuvier, 1816) (Campos et al., 2015b) on the lower stretch of the Solimões river.

\section{Acknowledgements}

The authors would like to thank the Fundação de Amparo à Pesquisa do Estado do Amazonas (FAPEAM) and the Conselho Nacional de Desenvolvimento Científico e Tecnológico $(\mathrm{CNPq})$ for providing financial support for this study.

\section{References}

ANDRADE, F., SCHNEIDER, H., FARIAS, I., FELDBERG, E. and SAMPAIO, I., 2001. Análise filogenética de duas espécies simpátricas de tucunaré (Cichla, perciformes), com registro de hibridização em diferentes pontos da bacia amazônica. Revista Virtual de Iniciação Acadêmica da UFPA, vol. 1, no. 1, pp. 1-11.

BARTHEM, R.B. and GOULDING, M., 2007. Um ecossistema inesperado: a Amazonia revelada pela pesca. Lima: Amazon Conservation Association, Sociedade Civil Mamirauá, 241 p.

BATISTA, V.S. and PETRERE JUNIOR, M., 2007. Spatial and temporal distribution of fishing resources exploited by the Manaus fishing fleet, Amazonas, Brazil. Brazilian journal of biology = Revista brasleira de biologia, vol. 67, no. 4, pp. 651-656. http:// dx.doi.org/10.1590/S1519-69842007000400009. PMid:18278316.

BATISTA, V.S., ISAAC, V.J., FABRÉ, N.N., ALONSO, J.C., ALMEIDA, O.T., RIVERO, S., OLIVEIRA-JÚNIOR, J.N., RUFFINO, M.L., SILVA, C.O. and SAINT-PAUL, U., 2012. Peixes e pesca no Solimões-Amazonas: uma avaliação integrada. Brasília: IBAMA, ProVárzea, 276 p.

BAYLEY, P.B. and PETRERE, M., 1989. Amazon fisheries: assessment methods, current status and management options. In: D.P. DODGE, ed. Proceedings of the Internacional Large River Symposium, 14-21 September 1986, Honey Harbour, Ontario. Ottawa: Canadian Special Publication of Fisheries and Aquatic Sciences, pp. 385-398.

BRINN, M.N.A., PORTO, J.I.R. and FELDBERG, E., 2004. Karyological evidence for interspecific hybridization between Cichla monoculus and C. temensis (Perciformes, Cichlidae) in the Amazon. Hereditas, vol. 141, no. 3, pp. 252-257. http:// dx.doi.org/10.1111/j.1601-5223.2004.01830.x. PMid:15703041.

CAMPOS, C.P. and FREITAS, C.E.C., 2014. Yield per recruit of the peacock bass Cichla monoculus (Spix and Agassiz, 1831) caught in Lago Grande at Manacapuru (Amazonas - Brazil). Brazilian Journal of Biology $=$ Revista Brasileira de Biologia, vol. 74, no. 1, pp. 226-230. http://dx.doi.org/10.1590/15196984.17312. PMid:25055107.

CAMPOS, C.P., AMADIO, S.A. and FREITAS, C.E.C., 2015a. Growth of the Cichla temensis Humboldt, 1821 (Perciformes, Cichlidae) from the middle Rio Negro, Amazonas, Brazil. Neotropical Ichthyology, vol. 13, no. 2, pp. 1-8. http://dx.doi. org/10.1590/1982-0224-20140090.

CAMPOS, C.P., SOUSA, R.G.C., CATARINO, M.F., COSTA, G.A. and FREITAS, C.E.C., 2015b. Population dynamics and stock assessment of Colossoma macropomum caught in the Manacapuru Lake system (Amazon Basin, Brazil). Fisheries Management and Ecology, vol. 22, no. 5, pp. 400-406. http:// dx.doi.org/10.1111/fme.12139.

CATARINO, M.F., CAMPOS, C.P., GARCEZ, R. and FREITAS, C.E.C., 2014. Population dynamics of Prochilodus nigricans caught in Manacapuru Lake (Amazon Basin, Brazil). Boletim do Instituto de Pesca, vol. 40, no. 4, pp. 589-595.

DIAS-NETO, J. and DIAS, J.F.O., 2015. O uso da biodiversidade aquática no Brasil: uma avaliação com foco na pesca. Brasília: IBAMA, $288 \mathrm{p}$.

FREITAS, C.E.C. and RIVAS, A.A.F., 2006. A pesca e os recursos pesqueiros na Amazônia Ocidental. Ciência e Cultura, vol. 58, no. 3 , pp. 30-32. SBPC. 
HOLLEY, M.H., MACEINA, M.J., THOMÉ-SOUZA, M. and FORSBERG, B.R., 2008. Analysis of the trophy sport fishery for the speckled peacock bass in the Rio Negro River, Brazil. Fisheries Management and Ecology, vol. 15, no. 2, pp. 93-98. http://dx.doi.org/10.1111/j.1365-2400.2007.00587.x.

INOMATA, S.O. and FREITAS, C.E.C., 2015. A Pesca comercial no médio rio Negro: aspectos econômicos e estrutura operacional. Boletim do Instituto de Pesca, vol. 41, no. 1, pp. 79-87.

ISAAC, V.J. and RUFFINO, M.L., 1996. Population dynamics of tambaqui, Colossoma macropomum Cuvier, in the Lower Amazon, Brazil. Fisheries Management and Ecology, vol. 3, no. 4, pp. 315-333. http://dx.doi.org/10.1046/j.1365-2400.1996.d01-154.x.

JEPSEN, D.B., WINEMILLER, K.O. and TAPHORN, D.C., 1997. Temporal patterns of resource partitioning among Cichla species in a Venezuelan blackwater river. Journal of Fish Biology, vol. 51, no. 6, pp. 1085-1108. http://dx.doi.org/10.1111/j.1095-8649.1997. tb01129.x. PMid:29991161.

JEPSEN, D.B., WINEMILLER, K.O., TAPHORN, D.C. and OLARTE, D.R., 1999. Age structure and growth of peacock cichlids from rivers and reservoirs of Venezuela. Journal of Fish Biology, vol. 55, no. 2, pp. 433-450. http://dx.doi. org/10.1111/j.1095-8649.1999.tb00689.x.

KING, M., 1995. Fisheries biology, assessment and management. Oxford: Fishing New Books, 341 p.

KULLANDER, S.O. and FERREIRA, E.J.G., 2006. A review of the South American cichlid genus Cichla, with descriptions of nine new species (Teleostei: cichlidae). Ichthyological Exploration of Freshwaters, vol. 17, no. 4, pp. 289-398.

LATRUBESSE, E.M. and FRANZINELLI, E., 2005. The late Quaternary evolution of the Negro River, Amazon, Brazil: implications for island and floodplain formation in large anabranching tropical system. Geomorphology, vol. 70, no. 3-4, pp. 372-397. http://dx.doi.org/10.1016/j.geomorph.2005.02.014.

MONTAÑA, C., TAPHORN, D., LAYMAN, C. and LASSO, C., 2007. Distribución, alimentación y reproducción de tres especies de pavones Cichla spp. (Perciformes, Cichlidae) en la cuenca baja del río Ventuari, Estado Amazonas, Venezuela. Memoria de la Fundación La Salle de Ciencias Naturales, vol. 165, pp. 83-102.

PAULY, D., 1980. On the interrelationships between natural mortality, growth parameters, and mean environmental temperature in 175 fish stocks. ICES Journal of Marine Science, vol. 39, no. 2, pp. 175-192. http://dx.doi.org/10.1093/icesjms/39.2.175.

RABELO, H. and ARAÚJO-LIMA, C.A.R.M., 2002. A dieta e o consumo diário de alimento de Cichla monoculus na Amazônia Central. Acta Amazonica, vol. 32, no. 4, pp. 707-724. http://dx.doi. org/10.1590/1809-43922002324724.

REISS, P., ABLE, K.W., NUNES, M.S. and HRBEK, T., 2012. Color pattern variation in Cichla temensis (Perciformes: Cichlidae): Resolution based on morphological, molecular, and reproductive data. Neotropical Ichthyology, vol. 10, no. 1, pp. 59-70. http:// dx.doi.org/10.1590/S1679-62252012000100006.

RUFFINO, M.L., 2014. Status and trends of fishery resources of the Amazon basin in Brazil. In: R.L. WELCOMME, J. VALBOJORGENSEN and A.S. HALLS, eds. Inland fisheries evolution and manegement: case studies from four continents. Roma: FAO Fisheries and Aquaculture, pp. 1-20. Technical Paper, no. 579.

SANT'ANNA, I.R.A., DORIA, C. and FREITAS, C.E.C., 2014. Pre-impoundment stock assessment of two Pimelodidae species caught by small-scale fisheries in the Madeira River (Amazon Basin - Brazil). Fisheries Management and Ecology, vol. 21, no. 4, pp. 322-329. http://dx.doi.org/10.1111/fme.12082.

SPARRE, P. and VENEMA, S.C., 1997. Introduction to tropical fish stock assessment - part 1: manual. Roma: FAO, 404 p. Documento Técnico sobre as Pescas, no. 306/1.

WILLIS, S.C., WINEMILLER, K.O., MONTAÑA, C.G., MACRANDER, J., REISS, P., FARIAS, I.P. and ORTÍ, G., 2015. Population genetics of the speckled peacock bass (Cichla temensis), South America's most important inland sport fishery. Conservation Genetics, vol. 16, no. 6, pp. 1345-1357. http:// dx.doi.org/10.1007/s10592-015-0744-y.

WINEMILLER, K. and ROSE, K.A., 1992. Patterns of lifehistory diversification in North American fishes: implications for population regulation. Canadian Journal of Fisheries and Aquatic Sciences, vol. 49, no. 10, pp. 2196-2218. http://dx.doi. org/10.1139/f92-242.

WINEMILLER, K.O., TAPHORN, D.C. and BARBARINODUQUE, A., 1997. Ecology of Cichla (Cichlidae) in two blackwater rivers of Southern Venezuela. Copeia, vol. 4, no. 4, pp. 690-696. http://dx.doi.org/10.2307/1447287. 